\title{
COVID-19 during malaria transmission season in Africa and why we should be prepared: An example from Senegal
}

\begin{tabular}{|c|c|}
\hline \multicolumn{2}{|c|}{$\begin{array}{l}\text { Authors: } \\
\text { Khadim Diongue }{ }^{1,2} \text { (1) } \\
\text { Mamadou A. Diallo }{ }^{2} \text { ( }\end{array}$} \\
\hline \multicolumn{2}{|c|}{$\begin{array}{l}\text { Affiliations: } \\
\text { Parasitology-Mycology } \\
\text { Service, Faculty of Medicine, } \\
\text { Pharmacy and Odontology, } \\
\text { Cheikh Anta Diop University, } \\
\text { Dakar, Senegal }\end{array}$} \\
\hline \multicolumn{2}{|c|}{$\begin{array}{l}\text { 2Laboratory of Parasitology } \\
\text { and Mycology, Aristide Le } \\
\text { Dantec University Hospital, } \\
\text { Dakar, Senegal }\end{array}$} \\
\hline \multicolumn{2}{|c|}{$\begin{array}{l}\text { Corresponding author: } \\
\text { Khadim Diongue, } \\
\text { khadimase@gmail.com }\end{array}$} \\
\hline \multicolumn{2}{|c|}{$\begin{array}{l}\text { Dates: } \\
\text { Received: } 08 \text { July } 2020 \\
\text { Accepted: } 14 \text { Sept. } 2020 \\
\text { Published: } 18 \text { Nov. } 2020\end{array}$} \\
\hline \multicolumn{2}{|c|}{$\begin{array}{l}\text { How to cite this article: } \\
\text { Diongue K, Diallo MA. } \\
\text { COVID-19 during malaria } \\
\text { transmission season in Africa } \\
\text { and why we should be } \\
\text { prepared: An example from } \\
\text { Senegal. Afr J Lab Med. } \\
\text { 2020;9(1), a1332. https://doi. } \\
\text { org/10.4102/ajlm.v9i1.1332 }\end{array}$} \\
\hline \multicolumn{2}{|c|}{$\begin{array}{l}\text { Copyright: } \\
\text { (c) 2020. The Authors. } \\
\text { Licensee: AOSIS. This work } \\
\text { is licensed under the } \\
\text { Creative Commons } \\
\text { Attribution License. }\end{array}$} \\
\hline \multicolumn{2}{|l|}{ Read online: } \\
\hline 回政四 & $\begin{array}{l}\text { Scan this QR } \\
\text { code with your } \\
\text { smart phone or } \\
\text { mobile device } \\
\text { to read online. }\end{array}$ \\
\hline
\end{tabular}

\section{Introduction}

Coronavirus disease 2019 (COVID-19) is not just a global health crisis; it is also a socio-economic crisis ${ }^{1}$ with a huge number of associated deaths. ${ }^{2}$ On 30 June 2020, the World Health Organization reported 10185374 cases and 503862 deaths related to COVID-19 globally, of which 297290 cases and 6010 deaths were recorded in Africa. ${ }^{1}$ In Senegal, malaria transmission is seasonal with high vector populations observed during the rainy season - from mid-June to October. The heaviest rainfalls are observed in the months of July, August and September. On 30 March 2020, as effort to combat the spread of COVID-19 in Senegal, a state of emergency was declared banning religious gatherings, closing schools and universities and imposing a curfew between 22:00 and 06:00. As of 30 June 2020, the day the state of emergency was lifted, the authorities had reported 6698 confirmed COVID-19 cases and 108 COVID-19 related deaths ${ }^{1,3,4}$ thus the country was confronted with managing the expected rainy-season malaria epidemic and the on-going COVID-19 pandemic. Hence, this article aims to draw the attention of authorities to this current situation.

\section{An important epidemiological reminder in this current context}

Before and after the ease of lockdown measures on 04 June 2020, Senegal had been experiencing constantly increasing COVID-19 cases, as evidenced by a $22 \%$ increase in cases during the month of June 2020. There were 1838 COVID-19 cases on 01 June 2020, which had reached 2249 cases by 30 June 2020. However, the most detrimental event during the COVID-19 pandemic is that of the general population deserting the health facilities that are hosting infected COVID-19 individuals for fear of being tested or infected. Since the decentralisation and proliferation of COVID-19 care centres around the country, COVID-19 hosting centres are being avoided by the populace; worse still, patients have now deserted the isolation centres. Senegalese people avoid going to places where any test that could suggest COVID-19 is done, even a body temperature measurement. However, experience has shown that in an outbreak such as the COVID-19 pandemic, it is essential to not ignore other diseases such as malaria. The recent West Africa Ebola epidemic revealed the deleterious impact of increased health service demand on an already fragile health system, as well as on the control of other diseases. Consequently, the Ebola outbreak led to a substantial increase in morbidity and mortality of other diseases, including malaria. ${ }^{5}$ The World Health Organization has warned of a twofold devastation by the COVID-19 pandemic: the first is its direct effect on health - COVID-19 morbidity and mortality - and the second is the related increase in morbidity and mortality of other diseases due to lack of or diversion of adequate health response for other diseases. ${ }^{5}$ For example, during the Ebola epidemic year in Guinea, health facilities recorded a lower malaria patients' visitation than was expected - an estimated deficit of 74000 visitations. Conversely and sadly, malaria caused 1067 deaths in 2014 - an Ebola year - compared to 108 deaths reported in 2013 - a non-Ebola year. ${ }^{6}$ More worryingly, in Liberia, Sierra Leone and Guinea, about 7000 other deaths related to malaria were recorded among children under age 5 years, which were attributed to the 2014-2016 Ebola outbreak. ${ }^{6}$

\section{What we know}

Malaria illness presents some similar symptoms to the COVID-19 illness: fever, respiratory distress, fatigue and an acute onset headache. ${ }^{5,7}$ The major sign between both illnesses is fever. Thus, a malaria case or a COVID-19 case may each be confused for the other, if symptoms alone 
are used to define a case during this current pandemic. Also, since the beginning of the pandemic in Senegal, fever is the major symptom of infected individuals ${ }^{8}$; febrile individuals are isolated before samples are taken. The sampling team is deployed after contact with the Senegalese medical emergency assistance service; however, the emergency assistance centre has been overwhelmed (more than 726000 emergency calls between 02 March 2020 and 29 June 2020 ), which could be the reason why, unfortunately, sampling teams can sometimes take more than $24 \mathrm{~h}$ to intervene. This delays the differential diagnosis of malaria and similar illnesses, as well as increases the risk of development of severe malaria, if malaria diagnosis is correct but delayed. Therefore, clinicians should go back to the good old method of 'any case of fever must be considered as malaria until proven otherwise'. Confirming either malaria or severe acute respiratory syndrome coronavirus 2 (SARS-CoV-2) infection with a diagnostic test does not rule out the possibility of the other in a patient. Indeed, both false-positive and falsenegative results have been reported worldwide with rapid diagnostic tests. ${ }^{10}$ Likewise, approximately 50\% of infected cases are likely missed by current screening approaches for COVID-19, even in countries with good healthcare systems and available diagnostic capacities. As COVID-19 can be transmitted even by asymptomatic people, and personal social distancing cannot be effective when performing a malaria test, such as a rapid diagnostic test, ${ }^{11}$ other infection prevention and control measures must be carefully put in place. ${ }^{7}$ These measures include but are not limited to: proper donning and doffing of personnel protection equipment, especially face masks; provision and use of soap and water for handwashing; provision and use of alcohol-based hand sanitiser and the practice of good respiratory hygiene (i.e. covering of the mouth and nose with a disposable tissue when sneezing or coughing or sneezing into the crease of the elbow). ${ }^{7}$ Thus, health providers should also be more careful.

\section{What we should do}

In Senegal, according to the last national malaria control programme report published in 2018, malaria caused 395706 cases with 284 deaths including 95 deaths (33.45\%) among children younger than age 5 years. ${ }^{12}$ However, the malaria burden was more than 50\% lower between 2009 and 2015, permitting the country to achieve the objectives of Roll Back Malaria in 2015. ${ }^{3}$ Therefore, to not lose this positive momentum in the fight against malaria, the Senegalese national malaria control programme should scrupulously follow the recommendations of the World Health Organization, which include tailoring malaria interventions in the COVID-19 response ${ }^{5}$ with particular regard to the following points: case management, chemoprevention (intermittent preventive treatment in pregnancy and seasonal malaria chemoprevention); extraordinary interventions, including presumptive treatment of fever and mass drug administration, as well as the assurance of continued access to and use of recommended insecticide-treated mosquito nets; and implementation of core vector-control activities to the greatest extent possible (current and planned insecticide-treated nets campaigns should go ahead, if at all possible). Malaria prevention and treatment is even more important during the COVID-19 pandemic than under normal circumstances.

Rapid diagnosis plays an important role in the outcome of both malaria and COVID-19; thus, in addition to these recommendations, quick, easy, reliable and cheap diagnostics requiring minimal invasion must be performed, especially in cases of likely overlap with malaria and COVID-19. This is the time for malaria-endemic countries challenged with the COVID-19 pandemic to apply modern techniques including point-of-care tests such as the Loop-Mediated Isothermal Amplification assay for rapid detection of both Plasmodium and SARS-CoV-2. ${ }^{13,14}$ Meanwhile, health authorities should also centralise the management of COVID-19 infected individuals so that populations suffering from other diseases (diabetes, high blood pressure, cardiovascular disorders, arthritis, etc.) could return to health facilities without fear of being infected. However, number of tests as well as the test centers for COVID-19 detection should be multiplied in order to attend benefits of early case identification.

\section{Acknowledgements}

We are thankful to Dr Mamane Nassirou Garba for his English review and all the staff of the parasitology and mycology laboratory at Le Dantec University of Dakar, especially to Prof. Daouda Ndiaye.

\section{Competing interests}

The authors declare that they have no financial or personal relationships that may have inappropriately influenced them in writing this article.

\section{Authors' contributions}

K.D. was responsible for the conception and design of the study and drafting the article. M.A.D. reviewed the article. All authors approved the final version to be submitted.

\section{Ethical considerations}

The work did not involve the use of human subjects or animal experiments.

\section{Sources of support}

This research received no specific grant from any funding agency in the public, commercial or not-for-profit sectors.

\section{Data availability statement}

Data sharing is not applicable to this article as no new data were created or analysed in this study.

\section{Disclaimer}

The views and opinions expressed in this article are those of the authors and do not necessarily reflect the official policy or position of any affiliated agency of the authors. 


\section{References}

1. World Health Organization (WHO). Coronavirus disease (COVID-19): Situation report - 162. WHO; 2020 [cited 2020 Jun 30]. Available from: www.who.int/ emergencies/diseases/novel-coronavirus-2019/situation-reports

2. Gangneux J-P, Bougnoux $M-E$, Dannaoui $E$, Cornet $M$, Zahar JR. Invasive fungal diseases during COVID-19: We should be prepared. J Mycol Méd. 2020;30(2):100971. https://doi.org/10.1016/j.mycmed.2020.100971

3. Programme National de Lutte contre le paludisme (PNLP). Sénégal - Plan Stratégique de lutte contre le Paludisme 2016-2020 [homepage on the Internet]. PNLP; 2015 [cited 2020 Jun 30]. http://www.pnlp.sn/wp-content/ uploads/2016/08/PNLP_PSN_VFF_03-02-2016.pdf

4. Agence Nationale de la Statistique et de la Démographie/Service Régional de la Statistique et de la Démographie de Dakar (ANSD/SRSD). Situation Économique et Sociale régionale - 2012 [homepage on the Internet]. ANSD/SRSD; 2015 [cited 2020 Jun 30]. Available from: http://www.ansd.sn/ressources/ses/SES Dakar-2012.pdf

5. World Health Organization (WHO). Tailoring malaria interventions in the COVID-19 response [homepage on the Internet]. WHO; 2020 [cited 2020 Jun 30]. Available from: http://www.who.int/malaria

6. Wang J, Xu C, Wong YK, et al. Preparedness is essential for malaria-endemic regions during the COVID-19 pandemic. Lancet. 2020;395(10230):1094-1096. https://doi.org/10.1016/S0140-6736(20)30561-4

7. Chanda-Kapata P, Kapata N. COVID-19 and malaria: A symptom screening challenge for malaria endemic countries. Int J Infect Dis. 2020;94:151-153. https://doi.org/10.1016/j.ijid.2020.04.007
8. Seydi M, Lakhe NA. Profil Épidémiologique, Clinique et Évolution des Cas de COVID-19 au Sénégal. Ministère de la santé et de l'action sociale [homepage on the Internet]. 2020 [cited 2020 Jun 30]. Available from: http://familyplanning2020. org/sites/default/files/resources/COVID/COVID-19\%20AFREHealth\%20 Webinar\%20Talk_CMIT_Dakar_Senegal_Pr.\%20Seydi_Dr.\%20Lakhe_ March19_2020_French\%20Version.pdf

9. Ministère de la Santé et de l'Action Sociale (MSAS). Message à la Nation de SEM le Président Sall Levée de l'état d'urgence instauré dans le cadre de la lutte contre la maladie à coronavirus COVID-19 [homepage on the Internet]. MSAS; 2020 [cited 2020 Jun 30]. Available from: http://www.sante.gouv.sn/sites/default/files/ DISCOURS\%20DU\%20PR.pdf

10. Kafai NM, Odom John AR. Malaria in children. Infect Dis Clin N Am. 2018;32(1): 189-200. https://doi.org/10.1016/j.idc.2017.10.008

11. Diallo MA, Diongue K, Ndiaye M, et al. Evaluation of CareStart ${ }^{\mathrm{TM}}$ Malaria HRP2/ $\mathrm{pLDH}$ (Pf/pan) combo test in a malaria low transmission region of Senegal. Malar J. 2017;16:328. https://doi.org/10.1186/s12936-017-1980-z

12. Programme National de Lutte contre le paludisme (PNLP). Bulletin épidémiologique annuel 2017 du paludisme au Sénégal [homepage on the Internet]. PNLP; 2018 [cited 2020 Jun 30]. Available from: https://fr.africacheck. org/wp-content/uploads/2018/04/Senegal-paludisme-bulletin-annuel-2017PNLP.pdf

13. Lucchi NW, Gaye M, Diallo MA, et al. Evaluation of the Illumigene Malaria LAMP A robust molecular diagnostic tool for malaria parasites. Sci Rep. 2016;6:36808. https://doi.org/10.1038/srep36808

14. L'Helgouach N, Champigneux P, Schneider FS, et al. EasyCOV: LAMP based rapid detection of SARS-CoV-2 in saliva [homepage on the Internet]. 2020 [cited 2020 Jun 30]. https://www.skillcell-alcen.com/sites/skillcell-alcen/files/pdf/press/ Clinical-assessment-of-EasyCov-v10_1.pdf 